This manuscript is an EarthArXiv preprint and has not been peer-reviewed before. Subsequent versions of this manuscript may have slightly different content.

\title{
Urban Flood Impact Assessment and Hazard Vulnerability Analysis: Iowa Case Study
}

$$
\text { Yazeed Alabbad }{ }^{\mathrm{a}, \mathrm{b}} \text {, Ibrahim Demir }{ }^{\mathrm{a}, \mathrm{c}}
$$

a Department of Civil and Environmental Engineering, University of Iowa, Iowa City, Iowa, US

${ }^{\mathrm{b}}$ Department of Civil Engineering, King Saud University, Riyadh, Saudi Arabia

${ }^{\mathrm{c}}$ IIHR - Hydroscience and Engineering, University of Iowa, Iowa City, Iowa, US

\begin{abstract}
Flooding is one of the most common natural disasters affecting communities worldwide. It is expected to persist with increasing magnitude and frequency as a result of climate change, resulting in both direct and indirect negative consequences. The flood impact assessment is considered as a key component of flood risk management strategies, such as benefit-cost analysis for mitigation planning. This study aims to provide a comprehensive assessment of socioeconomic impacts for the 100 and 500-year flood scenarios for major Iowa communities. The analysis includes impact on essential facilities, businesses, and vehicles, loss of life, amount of debris transported downstream, displaced population, and floodplain vulnerability classification. Due to the differences in the topography and the spatial distribution of buildings and infrastructure, and the absence of sufficient flood prevention measures within the study area, our findings illustrate that some communities will suffer significant damage and losses during flooding. This research could aid communities in making more effective decisions regarding damage reduction, prioritizing mitigation actions, and preparing for future flood events.
\end{abstract}


This manuscript is an EarthArXiv preprint and has not been peer-reviewed before. Subsequent versions of this manuscript may have slightly different content.

\section{Introduction}

Increased population, rapid urbanization, and climate change are all contributing to aggravate flood risk in communities around the world (Zhang et al., 2018; Wasko et al., 2021). Flooding can cause unexpected effects on people, properties, agriculture, and infrastructure and cause significant economic damage and loss of life. From 1980 to 2021, the annual flood disasters in the U.S. caused nearly $\$ 3.8$ billion in damage and killed 15 people (NOAA, 2021). Also, productivity, labor hours, and GDP may all be affected by flooding (Brown et al., 2013). The state of Iowa has been severely impacted by flood events over the past two decades. In 2019, flood disasters struck many parts of Iowa, causing an estimated $\$ 1.6$ billion in damage (Iowa.gov, 2019).

Flood risk changes over time for communities with severe consequences (Sadler et al., 2017). By 2100, the average projected 100-year floodplain will increase 45 percent, with annual floodrelated damage of 750 million (US EPA, 2020). State and local authorities perform measures (e.g., dams) to control floodwater. However, unexpected patterns of flooding lead to an increase in its magnitude and extent, so existing flood controls may not be able to withstand future flood events (NAI, 2014). Additional plans and strategies can be developed, such as riverine planning to better cope with, respond to, and recover from flood events in the long and short-term in order to minimize flood risk and increase the resilience of communities (United Nations, 2012).

Effective flood risk assessment leads to better understanding of flood risk and actions for flood resilience (Hammond et al., 2015). Flood risk can be defined as a combination of the probability of a flood event with the consequences associated with it (FEMA, 2016; CIRIA, 2013). In other words, when a flood hits a community (Risk), it can affect people and infrastructure (Exposure) and generate devastating economic, environmental, and social losses (Vulnerability). The flood risk assessment and management process include identifying the risk, evaluating the significance of the risk, and then taking actions to control and manage the risk (Bowles et al., 1999). The key question is how much risk there is, who it will affect, and how it will be mitigated. Identification and monitoring of flood events (Haltas et al., 2021) and risk and loss assessment have become necessary to prioritize mitigation projects, allocate resources, and analyze the benefit-cost of mitigation measures. Different stakeholders, including state and local governments, city planners, emergency response providers, and the public, can use the assessment to make successful flood risk mitigation decisions (Xu et al., 2020; Ewing and Demir, 2021). Web systems have been actively used in risk communication while providing extensive capabilities for terrain analysis (Sit et al., 2019) and geospatial forecasting (Xu et al., 2019).

Flood risk models coupled with the built environment have been studied extensively from different perspectives. Risk models can be used in flood risk management for risk communication (Weber et al., 2018) and evacuation plans (Radosavljevic et al., 2017). Researchers have explored flood damage on buildings (Yildirim \& Demir, 2021a; Brody et al.,2008), road network topology (Alabbad et al., 2021), and agriculture (Tapia-Silva et al., 
2011). In addition, Alabbad et al. (2022) developed a data analytics framework for efficient flood mitigation practices at the property level.

The potential flood-related damage, including physical, economic, and social, can be estimated using HAZUS model software developed by FEMA, which focuses on estimating the direct impacts of flood damage, including structure and content (Cummings et al., 2012; Yildirim $\&$ Demir, 2021b). Indirect losses such as business losses may be worse than the direct impacts. Assessment of direct and indirect losses provides a comprehensive picture of flood impacts and helps focus on effective projects to minimize the consequences. The absence of reliable methodologies and data may be an obstacle for estimating the indirect losses (Tate et al., 2015). Researchers have performed a comprehensive flood damage analysis, including indirect losses (e.g., business interruption) using HAZUS, and proven its capability in generating reliable results (Kousky et al., 2013; McGrath et al., 2015; Story County, 2018). FEMA accepts the estimated losses generated by HAZUS to be used for community flood hazard planning (NOAA, 2014). This planning is required for communities to obtain post-flood disaster funding from FEMA. Also, it could help develop strategies for flood mitigation, such as buyout and analyzing the costbenefit of the measures (Nelson \& Camp, 2020; Atoba et al., 2018).

Flooding can have an economic and functional impact on critical facilities (e.g., hospitals, fire departments). The necessity of these facilities during flooding becomes more critical than in normal circumstances due to its capability to provide essential services. For example, the fire department has a vital role in rescuing people from dangerous areas. However, these facilities might be already exposed to flooding, reducing their functionality. Qiang (2019) spatially analyzed critical infrastructure exposed to the 100-year flood extent in the U.S. with a limited focus on varying flood events and the functionality assessment.

The Hydrologic Engineering Center's Flood Impact Analysis (HEC-FIA) can assess riskbased analysis for the potential life loss during flooding (USACE, 2018). HEC-FIA is a geospatially based model for a single flood event that takes into account flood depths, detailed structure inventory with population, and evacuation information. It is considered as advanced software for life loss estimation (World Bank, 2014). Researchers have explored the capability of HEC-FIA to estimate the expected life loss resulting from dam failure (Mokhtari et al., 2017), storm surge (Brackins \& Kalyanapu, 2016), and levee breach case studies in the U.S. (Jonkman et al., 2013). Evacuation effectiveness is crucial for fatality number estimation (Jonkman et al., 2016). During the 2016 flood in Freeport, IA, the sound of the basement wall collapsing was the only flood notification for some people (Brummel et al., 2019). Based on the HEC-FIA findings, decision-makers can select appropriate measures (Teague et al., 2021) to reduce the potential loss of life, including ensuring early warning of major floods utilizing various technologies and approaches, evacuating planning, and shelter in place options.

The flood's depth, velocity, and duration are essential elements in determining flood losses (FEMA, 2020). Due to the complexity and uncertainty of producing detailed flood characteristics for each flood event, flood depth is considered reasonable to be employed to estimate floodrelated damage (USACE, 2003). However, other flood characteristics should be included to 
extract a wide range of advanced flood hazard assessments. The combination of flood depth and velocity can go beyond the traditional estimation of flood damage for floodplain risk classifications for better flood management (Australian Institute for Disaster Resilience, 2017). Researchers have studied flood depth-velocity $(\mathrm{DxV})$ functions to assess the stability of buildings (Jakob et al., 2012), vehicles (Xia et al., 2014), and people (Arrighi et al., 2017) during flooding. Smith et al. (2014) have created hazard classifications using the product of DxV for overall floodplain assessment as recommended by USACE (2020) and Australian Institute for Disaster Resilience (2017). Following the computation of flood consequences, flood risk management strategies such as resource allocation can be evaluated and prioritized.

This research requires significant resources and skills in data integration, spatial analysis, and computation (Agliamzanov et al., 2020), which may be a challenge for most communities with limited resources. Due to complex nature of flood risk and the significant adverse impacts associated with flooding, using tools such as HAZUS and HEC-FIA contributes to mitigation decisions in communities. They are considered the most comprehensive tools for flood risk assessment (Banks et al., 2014; Gutenson et al., 2015). Many Iowan communities lack flood hazard planning, which may lead communities not to be eligible for post-flood disaster funds from FEMA. Based on major scientific databases (i.e., Google Scholar), Iowa has produced detailed flood hazard impact analysis only for a limited number of communities (i.e., Story County, 2018).

This study focuses on addressing this need for a comprehensive flood loss estimation analysis for several Iowa communities during the 100 and 500-yr flood events, including damage to people, critical facilities, vehicles, and other building-related damage (e.g., relocation expenses, income losses). Also, there is a need to investigate areas prone to life losses during flooding in order to prepare well for future floods. To date, no previous analysis has examined the loss of life resulting from flood scenarios in Iowa. Our analysis investigates the potential life losses for major Iowa communities during the 100 and 500-yr flood scenarios. It can help decision-makers identify vulnerable population and areas, take mitigation actions such as moving the most vulnerable people out of the hazard areas and minimize the economic consequences. In addition, another focus of this research is to assess the vulnerability of people and the built environment to flooding using not only flood depth but also flood velocity. The study categorizes the floodplain areas into different classes based on the depth-velocity interaction for several Iowa communities to be used for deciding where to develop new residential areas and prioritizing flood risk management efforts (e.g., for evacuation routes to examine vehicle stability).

These assessments could increase knowledge regarding consequences resulting from flood events, provide a comprehensive insight into the vulnerability of Iowa communities to flooding and help make potential improvements within the floodplain, either structure or non-structural, to minimize flood-related losses and as a guide to improving the response to flooding and speed up the recovery. The rest of the paper is devoted to the flood loss and damage analysis methodology (section 2), including the case study, data preparation, and damage functions. Research results 
along with discussion are presented in section 3. The conclusion and further analysis follow these sections.

\section{Methodology}

\subsection{Case Study}

Iowa communities distribute in 99 counties with a total population of 3.1 million. The past two decades have seen a history of recurring flood events in Iowa, possessing serious damage to people, agriculture, and infrastructure at various levels. Our work provides a comprehensive look at the consequences of the 100 (1\% chance), and 500-year ( $0.2 \%$ chance) flood events on eight major Iowa communities named Des Moines, Cedar Rapids, Iowa City, Waterloo, Cedar Falls, Adel, and Independence, which have different topographical and residential surveys (Figure 1).

\subsection{Data Preparation}

Table 1 summarizes the datasets incorporated in this research to analyze the socio-economic impacts resulting from flood events. The datasets are collected from different sources, including but not limited to federal and state agencies (e.g., FEMA, USACE) and organizations. The interaction between flood models and building and vehicle inventory has led to the estimation of damage and losses to buildings, vehicles, and lives, as well as floodplain classification analysis. Building and vehicle depth-damage functions from HAZUS are utilized to extract the percentage of damage.

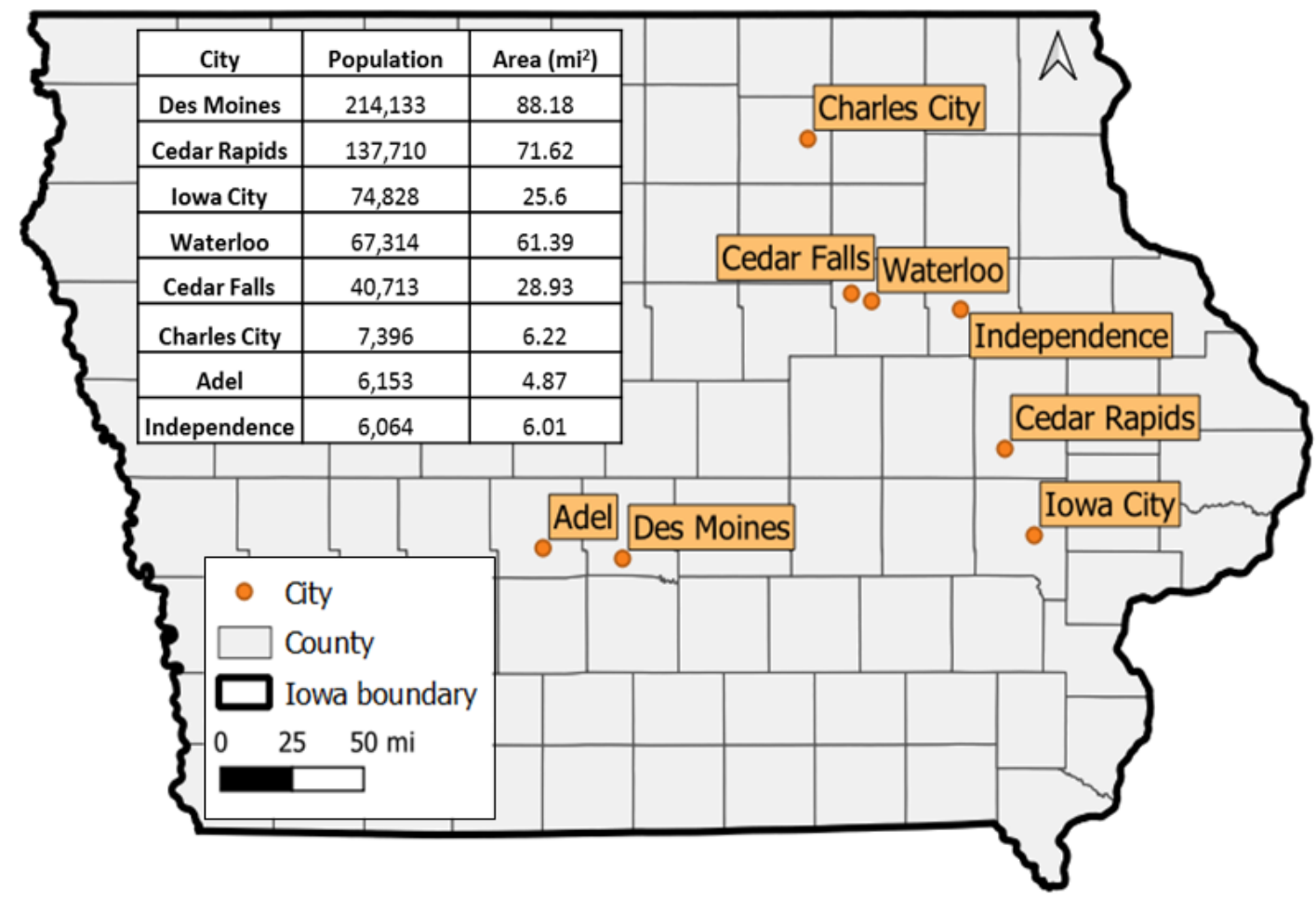

Figure1: The geo-spatial representation, population, and area for the analyzed cities. 
This manuscript is an EarthArXiv preprint and has not been peer-reviewed before. Subsequent versions of this manuscript may have slightly different content.

Table 1: Datasets with description and source information used in this research.

\begin{tabular}{|c|c|}
\hline Data & Description \\
\hline Flood model & $\begin{array}{l}\text { The model consists of 1-m flood depth and velocity raster for the inundated } \\
\text { area } \\
\text { Source: Iowa Flood Center (IFC) }\end{array}$ \\
\hline $\begin{array}{r}\text { Building } \\
\text { inventory \& } \\
\text { essential } \\
\text { facilities }\end{array}$ & $\begin{array}{l}\text { It includes building-spatial distribution and building-related information } \\
\text { (e.g., demographic, occupancy type, area) } \\
\text { Source: HAZUS, U.S. Census Bureau, HIFLD Open datasets, County Tax } \\
\text { Office }\end{array}$ \\
\hline $\begin{array}{r}\text { Essential facility } \\
\text { depth-damage } \\
\text { functions }\end{array}$ & $\begin{array}{l}\text { It defines the percentage of damage based on a flood depth and an } \\
\text { occupancy type } \\
\text { Source: HAZUS (2020) }\end{array}$ \\
\hline $\begin{array}{r}\text { Business } \\
\text { interruption } \\
\text { functions }\end{array}$ & $\begin{array}{l}\text { Equations include the cost of losses }(\$) \text { (e.g., income) per square foot for } \\
\text { different occupancy types, reconstruction times, \% recapture, and \% owned } \\
\text { occupied. } \\
\text { Source: HAZUS (2020) }\end{array}$ \\
\hline $\begin{array}{r}\text { Vehicle } \\
\text { inventory }\end{array}$ & $\begin{array}{l}\text { The inventory provides vehicle-spatial distribution, vehicle values, and } \\
\text { counts } \\
\text { Source: National Automobile Dealers Association (NADA), } 2000 \text { Census } \\
\text { building areas and } 2008 \text { Dun \& Bradstreet data }\end{array}$ \\
\hline $\begin{array}{r}\text { Vehicle depth- } \\
\text { damage } \\
\text { function }\end{array}$ & $\begin{array}{l}\text { It is the percentage of damage based on the flood depth and vehicle type } \\
\text { Source: HAZUS (2020) }\end{array}$ \\
\hline $\begin{array}{r}\text { Highway } \\
\text { bridges }\end{array}$ & $\begin{array}{l}\text { It is a database that contains a spatial representation of bridge points with } \\
\text { bridge-related information } \\
\text { Source: National Bridge Inventory (2018) }\end{array}$ \\
\hline Road segments & $\begin{array}{l}\text { It is a spatial representation of road networks } \\
\text { Source: OpenStreetMap (2020) }\end{array}$ \\
\hline $\begin{array}{r}\text { Life loss } \\
\text { functions }\end{array}$ & $\begin{array}{l}\text { It illustrates the fatality zones for each occupancy type and the average } \\
\text { fatality rate. } \\
\text { Source: HEC-FIA (2018) }\end{array}$ \\
\hline $\begin{array}{r}\text { Floodplain } \\
\text { classification }\end{array}$ & $\begin{array}{l}\text { Curves represent thresholds for floodplain vulnerability } \\
\text { Source: Smith et al. }(2014)\end{array}$ \\
\hline
\end{tabular}

Our analysis also requires building-related information (e.g., area) for business interruption functions. To estimate vehicle damage, it is required to determine the used and new vehicle costs and the type and number of vehicles within the impact area. Bridge damage during flooding is analyzed using information about highway bridges. The potential life loss during flooding is estimated according to flood depth, occupancy types, and the number of people occupying 
This manuscript is an EarthArXiv preprint and has not been peer-reviewed before. Subsequent versions of this manuscript may have slightly different content.

properties. Flood-prone areas are analyzed to examine the stability of people, vehicles, and buildings using the vulnerability curves.

Data integration and analysis have been performed in the GIS to produce the economic and human impacts during flooding. Figure 2 illustrates the research methodology for flood impact assessment, which includes three phases: HAZUS, HEC-FIA, and floodplain vulnerability. Sections $2.3,2.4$, and 2.5 provide detailed explanations of the approach used in each phase.

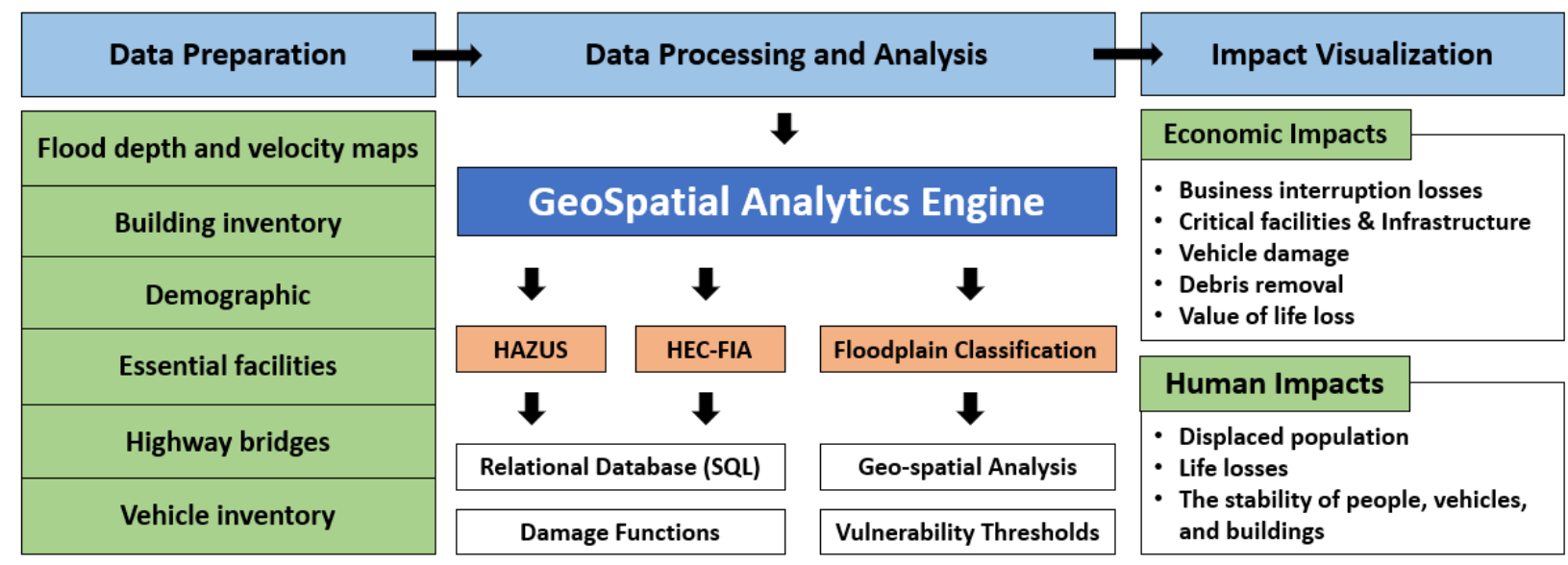

Figure 2. The overall methodology for the comprehensive flood loss and damage analysis.

\subsection{Community Flood Impact Analysis}

HAZUS utilizes Geographic Information System (GIS) to analyze data and generate potential flood-related losses (FEMA, 2020). HAZUS can be used to estimate a wide range of damage, including damage to people, buildings, vehicles, and infrastructure. It can operate at three levels based on the available data, user expertise, and spatial scale analysis. Level 1 analysis produces results using default HAZUS data and models. Level 2 analysis requires a combination of default HAZUS data with more detailed user-supplied data (e.g., high-resolution flood model and updated inventory data). The user can incorporate data resulting from more advanced studies and models, such as modifying the depth-damage function, into the Level 3 analysis. In this research, Level 2 analysis was performed to estimate flood hazard damage. We incorporated flood simulation models from Iowa Flood Center (IFC) while building, vehicle, and other infrastructure inventory data extracted directly from the HAZUS inventory database. HAZUS depth-damage functions are employed to estimate damage associated with different flood return periods.

HAZUS can run the analysis at different spatial scales using a national inventory database. The census block level is the smallest spatial scale. HAZUS distributes buildings evenly, which may affect the accuracy of the results. For example, HAZUS may count damage for unflooded buildings located inside partially flooded census blocks. Our analysis is performed on urban regions where buildings tend to be uniformly distributed per census block (Tate et al., 2015). User-defined data from tax assessor offices can improve the spatial representation of structures and gain accurate flood loss estimation (Ghimire \& Sharma, 2021). Direct damage to structure 
and content within the study area has been studied extensively by our team (Yildirim \& Demir, 2019). Our work focuses on other flood-related damage and losses, including business interruption, displaced population and shelter needs, vehicle damage, essential facilities, and infrastructure damage, and transported debris.

\subsubsection{Business Interruption}

Business interruption includes income, relocation, rental, and wage losses. Equations and parameters associated with each loss are presented as follows:

Income losses: This estimation relies on the restoration time, income recapture factor, income per day, and area of occupancy (Equation 1). The losses cover each building subjected to flooding.

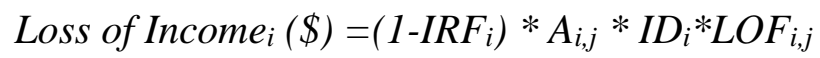

where all $i$ belongs to a specific occupancy and all $j$ belongs to a specific flood depth, IRF $F_{\mathrm{i}}$ is the income recapture factor, $A_{i, j}$ is the occupancy area, $\mathrm{ID}_{\mathrm{i}}$ is the income per day (per square foot), and $\mathrm{LOF}_{\mathrm{i}, \mathrm{j}}$ is the loss of function time (days).

Relocation losses: Occupants need to relocate once a building reaches a damage threshold of $10 \%$. The damage costs include shifting and transferring (disruption costs) as well as renting a temporary place. Some occupancies (e.g., theaters) will not be considered under this estimation. Relocation expenses can be estimated through the area of occupancy, disruption, and rental costs, recovery time, and percent owner-occupied (Equation 2).

Relocation Expenses $_{i}(\$)=A_{i, j} *\left[\left(1-\% O O_{i}\right) *\left(D C_{i}\right)+\% O O_{i} *\left(D C_{i}+R E N T_{i} * R T_{i, j}\right)\right]$

where all $i$ belongs to a specific occupancy and all $j$ belongs to a specific flood depth, $\mathrm{A}_{\mathrm{i}, \mathrm{j}}$ is the occupancy area, $\mathrm{OO}_{\mathrm{i}}$ is the percent owner occupied, $\mathrm{DC}_{\mathrm{i}}$ is the disruption cost, $\mathrm{RENT}_{\mathrm{i}}$ is the rental cost, and $\mathrm{RT}_{\mathrm{i}, \mathrm{j}}$ is the recovery time (days).

Rental losses: It can be estimated through the area of occupancy, rental costs, recovery time, and percent owner-occupied (Equation 3). The losses are calculated for buildings with damage of more than $10 \%$.

$$
\operatorname{Rental~Losses}_{i}(\$)=\left(1-\% O O_{i}\right) * A_{i, j} * R E N T_{i} * R T_{i, j}
$$

where all $i$ belongs to a specific occupancy and all $j$ belongs to a specific flood depth, $\mathrm{OO}_{\mathrm{i}}$ is the percent owner occupied, $\mathrm{A}_{\mathrm{i}, \mathrm{j}}$ is the occupancy area, $\mathrm{RENT}_{\mathrm{i}}$ is the rental cost, and $R \mathrm{~T}_{\mathrm{i}, \mathrm{j}}$ is the recovery time (days). 
Wage losses: This estimation relies on the restoration time, wage recapture factor, wage per day, and area of occupancy (Equation 4). The losses cover each building exposed to flooding.

$$
\text { Wage Losses }_{i}(\$)=\left(1-W R F_{i}\right) * A_{i, j} * W D_{i} * L O F_{i, j}
$$

where all $i$ belongs to a specific occupancy and all $j$ belongs to a specific flood depth, $\mathrm{WRF}_{\mathrm{i}}$ is the wage recapture factor, $\mathrm{A}_{\mathrm{i}, \mathrm{j}}$ is the occupancy area, $\mathrm{WD}_{\mathrm{i}}$ is the wage per day (per square foot), and $\mathrm{LOF}_{\mathrm{i}, \mathrm{j}}$ is the loss of function time (days).

\subsubsection{Displaced Population and Shelter Needs}

The displaced population is determined once the flood depth equals or is more than $0.5 \mathrm{ft}$. Estimating the number of people who need public shelters due to flooding depends on displaced people with factors related to age information and household income acquired from the US Census database.

\subsubsection{Vehicle Damage}

Vehicle damage estimation involves data about the distribution of vehicles during day and night, vehicle values, and damage function percentage associated with the flood depth. Based on the occupancy type and its square footage, HAZUS estimates the number of vehicles parked in an area. Then, a utilization percentage is assigned regarding the day and nighttime in order to estimate the actual number of vehicles. The vehicular depth damage functions are classified into three categories; car, light truck, and heavy truck, allowing users to calculate the percentage of damage according to area-weighted depth damage (Figure 3).

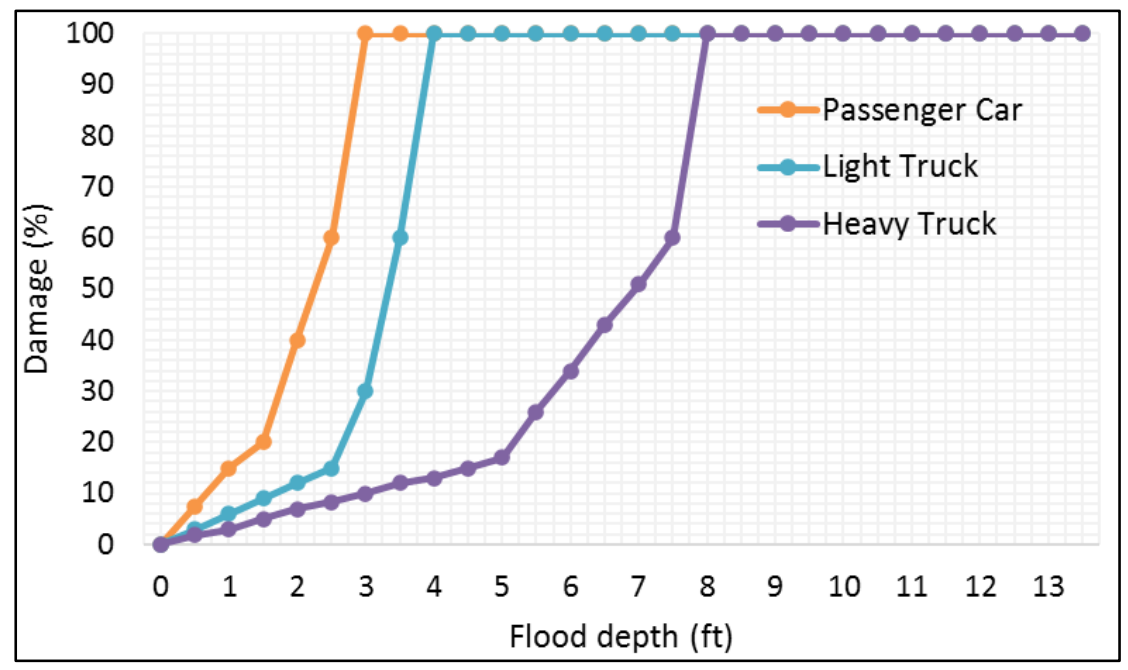

Figure 3: Vehicle depth-damage functions (HAZUS, 2020). 
The vehicle damage cost of a census block will be the percentage of the census block affected at a given flood depth multiplied by the percentage of damage at that depth multiplied by the vehicle values (Equation 5).

$$
\text { Vehicle damage }(\$)=(\%) \mathrm{D}_{\mathrm{i}, \mathrm{j}} *(\%) \mathrm{CB}_{\mathrm{j}} * \mathrm{VV}(\$)
$$

where all $i$ belongs to a specific occupancy and all $j$ belongs to a specific flood depth, $\mathrm{D}_{\mathrm{i}, \mathrm{j}}$ is the damage percentage, $\mathrm{CB}_{\mathrm{j}}$ the percentage of impacted census block, and $\mathrm{VV}$ is the vehicle value.

\subsubsection{Essential Facilities and Infrastructure Damage}

Critical facilities (e.g., police station) and utilities (e.g., treatment plants) are represented as a point location and classified into different occupancy types. As an assumption, some facilities will have a basement and others not. The model can estimate their potential direct impacts of flooding, including functionality assessment using the depth level at their point-representation. The analysis assigns default replacement and content values based on the occupancy type. The flood depth will allow users to estimate the damage percentage from depth-damage curves for each occupancy type (Table 2, Figure 4) and, then the amount of damage is determined (Equation 6). The damage functions provided in this section are only for essential facilities and utilities impacted withing the study area. Additional damage functions (e.g., hospitals) can be found in HAZUS software package.

$$
\text { Loss }(\$)=(\%) \mathrm{D} * \mathrm{IV}(\$)
$$

where $\mathrm{D}$ is the damage percentage at a given flood depth and IV is the inventory value.

The national bridge inventory database can be accessed to extract and represent the geolocation of the bridges. Highway bridge damage is based on the bridge cost, scour potential rating, and the flood scenario. The scour rate for a bridge range from 0 to 9 . The lowest rate means that the bridge is closed due to scouring, and nine indicates that the bridge is open. HAZUS focuses on bridge scour rating from 1 to 3 for damage estimation. Above this rate, the bridge would not be likely damaged. The probability of bridge failure depends on the number of spans for a bridge. For example, during the 100-yr flood, bridges rated as three will be $1 \%$ and $0.25 \%$ failure probability for single and continuous bridges, respectively. The damage cost is determined by multiplying the probability of failure by the bridge cost, and functionality can be estimated (1- the likelihood of failure).

Table 2: The percentage of damage for wastewater treatment plant (HAZUS, 2020).

\begin{tabular}{c|c|c|c|c|c|c|c|c|c|c|c}
\hline Flood depth $(\boldsymbol{f t})$ & $\mathbf{0}$ & $\mathbf{1}$ & $\mathbf{2}$ & $\mathbf{3}$ & $\mathbf{4}$ & $\mathbf{5}$ & $\mathbf{6}$ & $\mathbf{7}$ & $\mathbf{8}$ & $\mathbf{9}$ & $\mathbf{1 0}$ \\
\hline Damage $(\%)$ & 0 & 5 & 8 & 10 & 17 & 24 & 30 & 30 & 30 & 30 & 40 \\
\hline
\end{tabular}




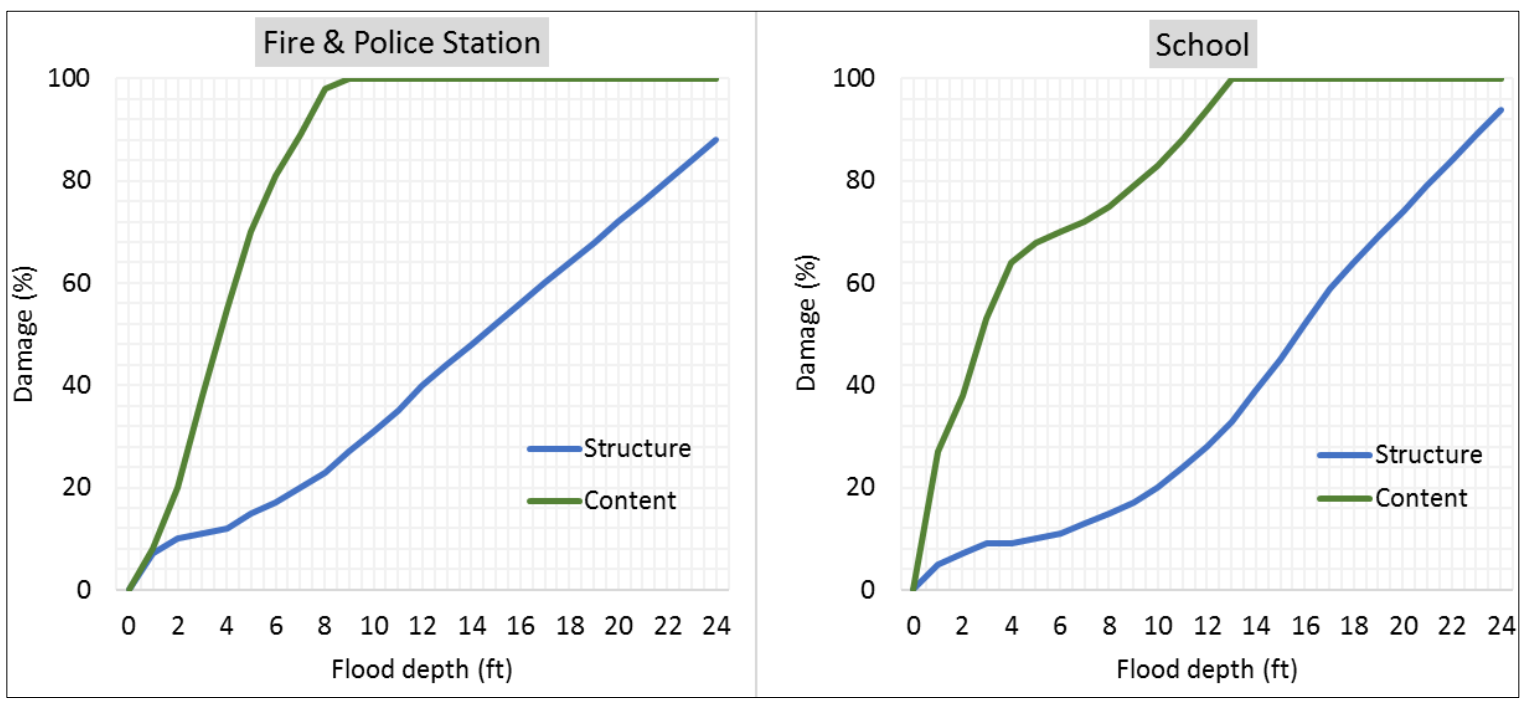

Figure 4: Depth-damage functions for essential facilities (HAZUS, 2020).

\subsubsection{Transported Debris}

The amount of flood debris transported downstream will be a result of building-related damage. The debris could include finishes (e.g., carpeting), structural components, and foundation materials. The analysis relies on occupancy area, flood depth, and foundation types to estimate the debris weight (ton) following a flood event (Table 3). The removal cost is assumed to be $\$ 18.50$ per cubic yard (FEMA, 2020).

\subsection{Life Loss Assessment During Flood Events}

Expected life losses associated with people's movement and behavior during a flood event can be determined using HEC-FIA software (USACE, 2018) which utilizes the simplified LIFESim methodology and runs the analysis using GIS. The necessary geospatial data to carry out the analysis are flood depth and extent, flood arrival time, detailed building inventory, and evacuation information. HEC-FIA can access the HAZUS database to import building inventory data into the study area, including population distribution. HEC-FIA uses an algorithm to redistribute people based on day and nighttime.

The amount of time that the population has to evacuate from the hazard area is the core component in estimating life loss. Thus, determination of the evacuation time needs detailed information about the evacuation routing, warning delay time, warning diffusion time, and protective action initiation time. HEC-FIA assumes that people will move out of the hazard areas horizontally (shortest path). Also, once the flood depth reaches $2 \mathrm{ft}$ at a building (the end of the opportunity to evacuate a structure), the model will implement vertical evacuation. 
Table 3: An example of the amount of debris resulting from flooding (FEMA, 2020).

\begin{tabular}{|c|c|c|c|c|c|}
\hline \multirow[t]{3}{*}{ Occupancy Type } & \multirow{3}{*}{$\begin{array}{c}\text { Flood } \\
\text { depth } \\
(\mathbf{f t})\end{array}$} & \multicolumn{4}{|c|}{ Debris weight (ton/1000sq.ft) } \\
\hline & & \multirow[t]{2}{*}{ Finishes } & \multirow[t]{2}{*}{ Structure } & \multicolumn{2}{|c|}{ Foundation } \\
\hline & & & & Footing & Slab on Grade \\
\hline \multirow{3}{*}{$\begin{array}{l}\text { Single Family Dwelling } \\
\text { (With no basement) }\end{array}$} & $0-4$ & 4.1 & - & - & - \\
\hline & $4-8$ & 6.8 & - & - & - \\
\hline & $>8$ & 6.8 & 6.5 & 12 & 25 \\
\hline
\end{tabular}

Three fatality zones (safe, compromised, chance) will be assigned for the impacted buildings depending on the maximum water depth and occupancy type (Figure 5). The fatality zones and their details described below:

Safe: The structure is usually dry or exposed to little or shallow floods unlikely to knock people off their feet. The average fatality rate for this zone is 0.0002 .

Compromised: The structure has been severely damaged by the flood, exposing people to dangerous floodwater. Its average fatality rate is 0.12 .

Chance: Flood victims are often washed downstream or stuck underwater, and their survival is primarily dependent on chance. The average fatality rate is 0.9145 .

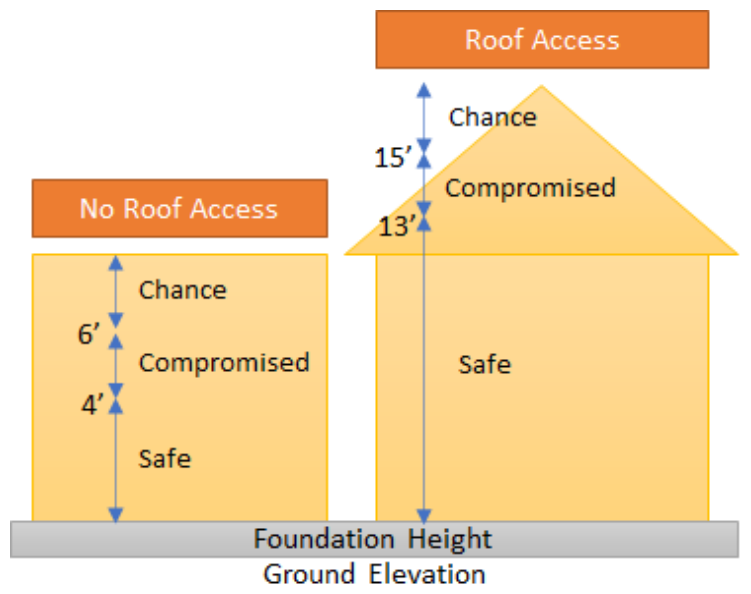

Figure 5: An example of fatality zones for a one-story building (USACE, 2018).

Flooding may happen unexpectedly or with little notice (Matthews et al., 2019). Even though there is a warning system (e.g., siren), flooding can strike communities at night where people fall asleep, ignoring the warning. Therefore, it is crucial to ensure that people will not be in the greatest danger of staying home during flooding. Our analysis will consider that people will remain in their homes during the 100 and 500-yr flood events, which means that impacted people have to evacuate vertically. The potential life losses are estimated by multiplying the number of people caught in buildings by the average fatality rate. We consider the largest number of life losses from the day and night, and then the analysis will show the benefit of avoiding life losses in 2021 dollar amounts (\$7.9 million/life) (FEMA, 2016). 


\subsection{Floodplain Vulnerability Analysis}

Flood hazard classification is based on hazard vulnerability curves proposed by (Smith et al., 2014) and recommended by (USACE, 2020; Australian Institute for Disaster Resilience, 2017). It is built into six vulnerability zones by employing the combination of flood depth and velocity $(\mathrm{DxV})$. It can inform spatial mapping of hazardous areas to vehicles, buildings, and people within the floodplain. As a result, mitigation activities can be performed, such as prioritizing regions for evacuation. The combined hazard vulnerability curves can be used for baseline hazard classification (Figure 6). It sets threshold criteria to determine vulnerable people, vehicles, and buildings. Additional specific hazard classifications can be more appropriate than the baseline classification assessment (Smith et al., 2014).

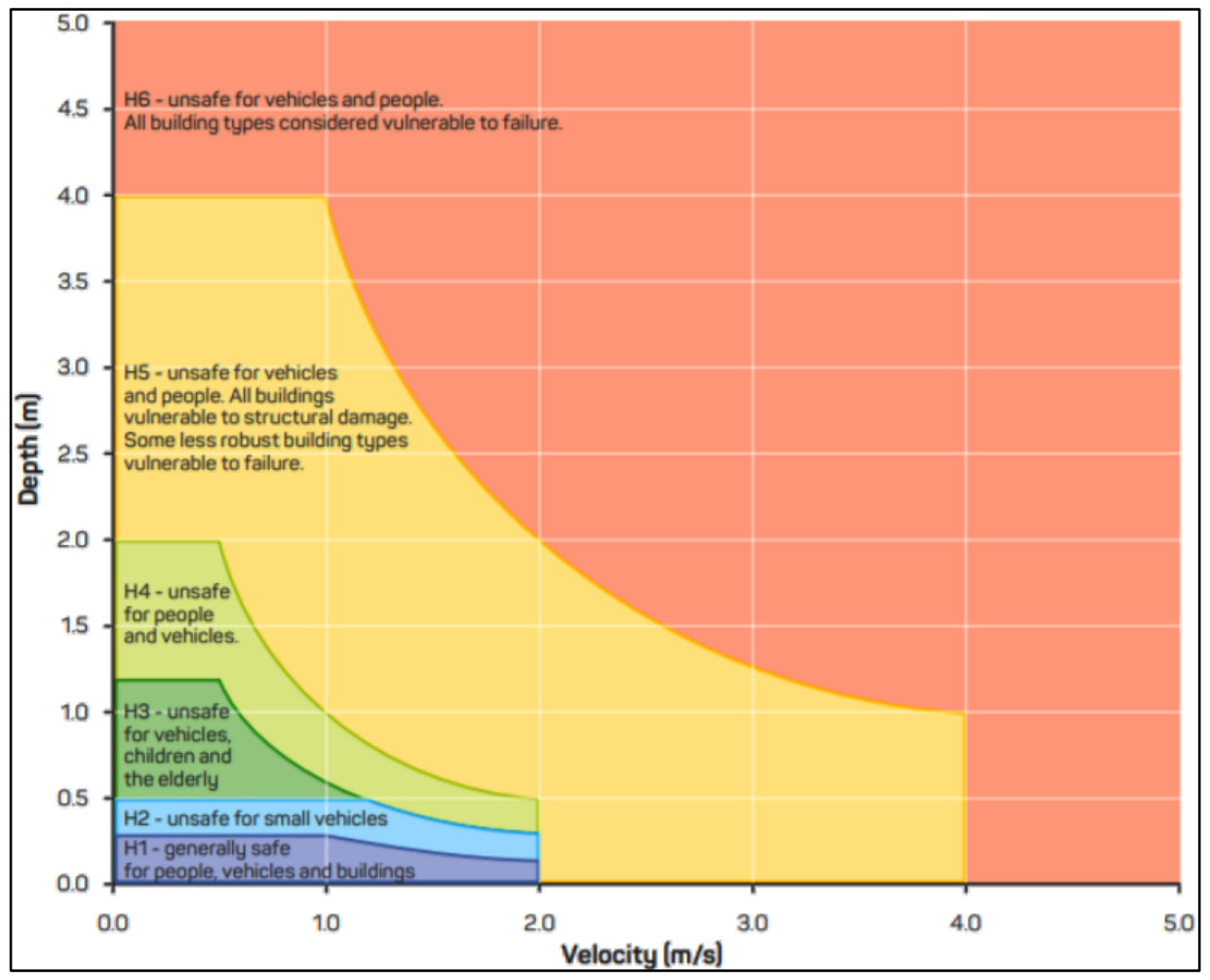

Figure 6: Floodplain vulnerability threshold adapted from (Smith et al., 2014)

For example, in evacuation scenarios, specific people and vehicle stability curves can be used to assess the evacuation routes. These vulnerability curves are based on an international literature search. Experiments utilize the relationship between a person (height $\mathrm{X}$ mass) and flow regime $(\mathrm{DxV})$ to provide guidelines for people's safety and stability in floods. In this research, flood behavior impacts on the 100 and 500-yr floodplain will be analyzed using flood hazard vulnerability curves. Integration, geoprocessing, and visualization of layers have been performed using GIS. After generating the floodplain vulnerability maps, two-dimensional interaction has 
been performed between the risk map and the built environment (buildings, road segments) to identify unsafe locations within the studied communities.

\section{Results and Discussion}

\subsection{Community Flood Impact Analysis}

This section presents and discusses the economic and human impacts of flood-related damage and losses (i.e., businesses, vehicles, displaced population and shelter needs, essential facilities and infrastructure, debris removal) for the selected communities.

Business Interruption: As can be seen in Figure 7, the business interruption losses during the 100 and 500-year floods are estimated for the selected communities. It is obvious that wage losses are the most affected, while losses from rental income seem relatively the least affected during the two flood scenarios. The figure shows that Cedar Rapids and Waterloo losses increases even though the population and areas go down.

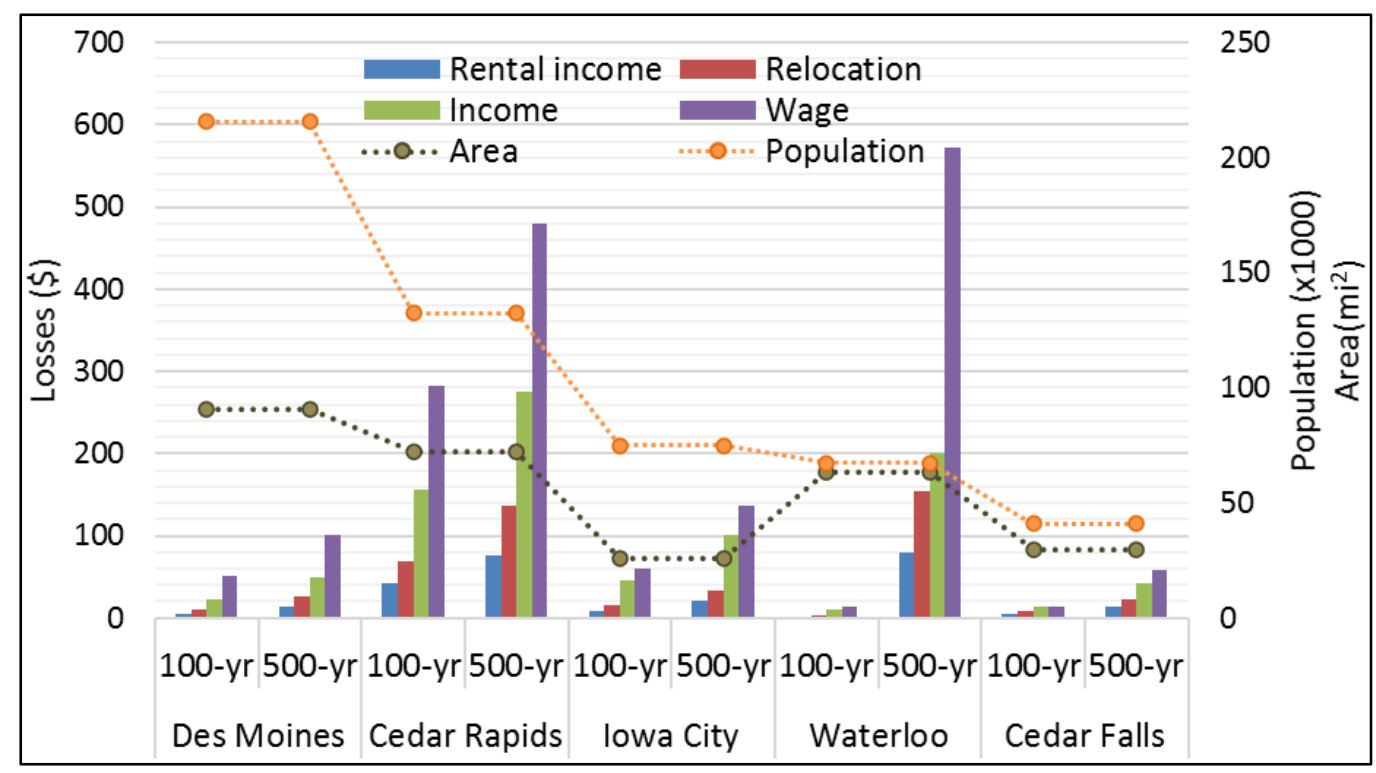

Figure 7: Business interruption losses (Millions of dollars) sorted by population.

Des Moines, the largest city in Iowa in terms of population and area, was found to be resilient to flooding compared to Cedar Rapids and Waterloo, which their losses approximately two times and more than what Des Moines will experience during flooding. The estimated total business interruption losses for the analyzed cities during the 100 and 500-yr flood events are $\$ 836 \mathrm{M}$ and $\$ 2.5 \mathrm{~B}$, respectively. We found that the variation in business interruption losses is attributed to the increase of buildings exposed to floods. Therefore, eliminating development in floodplains and relocating the impacted buildings to safe locations can contribute to minimizing the business interruption losses.

Displaced Population and Shelter Needs: Floods can last for days or weeks, so people have to move from hazardous areas to safe places. Not all affected people can pay for temporary relocation rooms, so the analysis considers income and age for estimating persons seeking 
shelters. Communities show differential impacts in terms of the number of displaced populations during flooding (Table 4). During the 100-yr flood, 2,516 people of Cedar Rapids will have to seek temporary shelter. Also, the 500-yr flood will affect approximately $22 \%$ of Waterlo's population significantly. That can be attributed to the number of buildings impacted by flooding.

Table 4: Number of displaced population and persons seeking shelter during flooding.

\begin{tabular}{|c|c|c|c|c|}
\hline \multirow{2}{*}{ City } & \multicolumn{2}{|c|}{ 100-yr flood } & \multicolumn{2}{c|}{ 500-yr flood } \\
\cline { 2 - 5 } & $\begin{array}{c}\text { Displaced } \\
\text { population }\end{array}$ & $\begin{array}{c}\text { People seeking } \\
\text { shelter }\end{array}$ & $\begin{array}{c}\text { Displaced } \\
\text { population }\end{array}$ & $\begin{array}{c}\text { People seeking } \\
\text { shelter }\end{array}$ \\
\hline Des Moines & 479 & 13 & 1,475 & 67 \\
\hline Cedar Rapids & 2,516 & 115 & 6,290 & 296 \\
\hline Iowa City & 1,224 & 99 & 2,220 & 205 \\
\hline Waterloo & 174 & 2 & 15,306 & 1,104 \\
\hline Cedar Falls & 668 & 38 & 1,115 & 75 \\
\hline
\end{tabular}

Vehicle Damage: Vehicles can experience damage and cause significant losses based on the flood depth and the type and distribution of vehicles. The distribution of day and night vehicles is based on the occupancy type of the buildings. Figure 8 shows the total vehicle damage for the studied communities during the 100 and 500-yr flood scenarios. The analysis indicates that vehicle losses during the day appear to be more severe than night losses. That could be a result of shutting down businesses that lead to empty vehicle parking lots at night. Also, we found a positive correlation between the number of affected buildings and the vehicle losses. However, the population and area of communities appear not strongly connected to increased vehicle losses, as can be seen for Des Moines. Also, some communities show a big shift in losses between the two flood events, as estimated for Cedar Rapids and Waterloo. Early flood warning helps move vehicles out of hazard areas and avoid losses.

Essential Facilities and Infrastructure Damage: The damage costs associated with the impacted essential facilities and infrastructure during flooding are presented in Table 5. The dollar losses include structure and content damage. Under the 100-yr flood, we noticed only Cedar Rapids could experience damage to one of its police stations and bridges with a total estimated loss of \$2.4 M. During the 500-yr flood event, most of the studied communities can experience damage to some essential facilities and bridges. The total damage estimation will be approximately $\$ 77 \mathrm{M}$. Waterloo will have severe impacts during the 500-yr since fire departments (count:3), police stations (count:2), and schools (count:3) are not safe from flooding. Allocation of amenities in Iowa City appears to be less vulnerable to flooding. No critical amenity was damaged in Iowa City during the 100 and 500-yr flood events. Also, all impacted amenities will be non-functional except the fire and police stations in Cedar Falls. Relocation of critical amenities or using flood mitigation measures help reduce damage and speed up the response to emergency cases during flooding. 


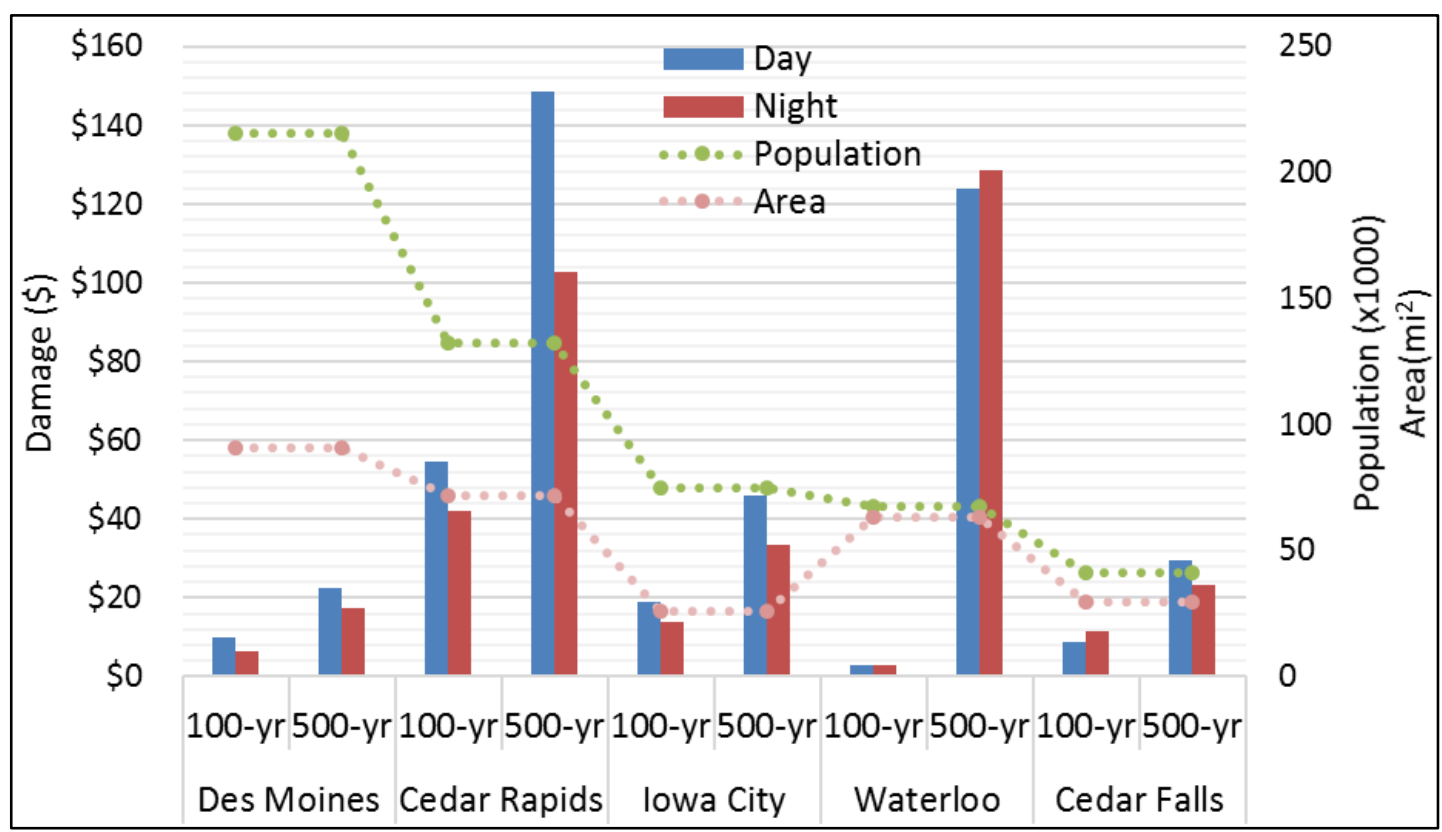

Figure 8: Day and night vehicle damage (in \$Million) sorted by population.

Table 5: Damage to essential facilities and infrastructure $(\$ 1000 \mathrm{~s})$

\begin{tabular}{|c|c|c|c|c|c|c|c|c|c|c|c|c|c|c|}
\hline \multirow[b]{3}{*}{ Facilities } & \multicolumn{3}{|c|}{ Des Moines } & \multicolumn{3}{|c|}{ Cedar Rapids } & \multicolumn{2}{|c|}{ Iowa City } & \multicolumn{3}{|c|}{ Waterloo } & \multicolumn{3}{|c|}{ Cedar Falls } \\
\hline & 100 & 500 & \# & 100 & 500 & $\#$ & 100 & 500 & 100 & 500 & \# & 100 & 500 & \# \\
\hline & yr & $\mathbf{y r}$ & & yr & $\mathbf{y r}$ & & yr & yr & $\mathbf{y r}$ & yr & & $\mathbf{y r}$ & $\mathbf{y r}$ & \\
\hline $\begin{array}{r}\text { Fire } \\
\text { Department }\end{array}$ & - & - & - & - & - & - & - & - & - & $\$ 4,187$ & 3 & - & $\$ 217$ & 1 \\
\hline $\begin{array}{l}\text { Police } \\
\text { Station }\end{array}$ & - & - & - & $\$ 2,367$ & $\$ 4,419$ & 1 & - & - & - & $\$ 4,092$ & 2 & - & $\$ 46$ & 1 \\
\hline School & - & $\$ 7,750$ & 1 & - & $\$ 1,845$ & 1 & - & - & - & $\$ 2,486$ & 3 & - & - & - \\
\hline $\begin{array}{r}\text { Wastewater } \\
\text { treatment } \\
\text { plant }\end{array}$ & - & - & - & - & - & - & - & - & - & - & - & - & $\$ 51,682$ & 1 \\
\hline $\begin{array}{r}\text { Highway } \\
\text { bridge }\end{array}$ & - & $\$ 50$ & 1 & $\$ 41$ & $\$ 81$ & 1 & - & - & - & - & - & - & $\$ 8$ & 1 \\
\hline
\end{tabular}

Debris Removal Cost: Debris amounts resulting from building damage during the 100-yr and 500-yr flood events are illustrated in Table 6. Cedar Falls generates the highest amount of debris under the 100-yr flood, while Waterloo shows significant amounts of debris during the 500-yr flood. Although Des Moines has the largest population and area among the studied areas, the debris estimation appears the lowest compared to the other communities during the two scenarios. The total cost of removing the debris during the two flood scenarios is $\$ 0.7 \mathrm{M}$ and $\$ 3.6 \mathrm{M}$, respectively. 
Table 6: The amount of debris and removing cost sorted by population.

\begin{tabular}{|c|c|c|c|c|}
\hline \multirow{2}{*}{ Cities } & \multicolumn{2}{|c|}{ Debris (ton) } & \multicolumn{2}{c|}{ Removing cost $(\$)$} \\
\cline { 2 - 5 } & $\mathbf{1 0 0}-\mathbf{y r}$ & $\mathbf{5 0 0}-\mathbf{y r}$ & $\mathbf{1 0 0}-\mathbf{y r}$ & $\mathbf{5 0 0}-\mathbf{y r}$ \\
\hline Des Moines & 881 & 5,833 & $\$ 32,597$ & $\$ 215,821$ \\
\hline Cedar Rapids & 6,752 & 21,933 & $\$ 249,824$ & $\$ 811,521$ \\
\hline Iowa City & 1,541 & 4,889 & $\$ 57,017$ & $\$ 180,893$ \\
\hline Waterloo & 2,164 & 46,455 & $\$ 80,068$ & $\$ 1,718,835$ \\
\hline Cedar Falls & 7,624 & 19,374 & $\$ 282,088$ & $\$ 716,838$ \\
\hline
\end{tabular}

\subsection{Life Loss Assessment During Flood Events}

We investigated the expected life loss during the 100-yr and 500-yr flood scenarios. Since flooding can happen without or with little warning, we assume that all people decided to remain in their homes during flooding. Vertical evacuation for each occupancy will be applied. Based on the occupancy type, population, and the maximum flood depth, the analysis will assign lethality zones (Safe, Compromised, Chance) for each building exposed to more than $2 \mathrm{ft}$ flood depth. Then, we used the average fatality rate (Chance: $91 \%$, Compromised: $12 \%$, Safe: $0.02 \%$ ) in the literature for people inside affected buildings. Five communities are selected to carry out the life loss analysis.

It is noted that the studied communities are differentially vulnerable to life losses during the two flood events (Table 7). Although Cedar Rapids is the highest in population among the studied communities, its buildings have little life loss impacts compared to other studied cities. That may be attributed to the existence of efficient flood controls (e.g., levee) or the location of buildings away from the waterways. On the other hand, Charles City appears to experience significant life losses (50 lives) during the 100-yr flood scenario, while Waterloo is the most vulnerable to life losses among the studied communities under the 500-yr flood with an estimate of 245 lives. Also, when compared to the 100-year scenario, the number of lives lost in the analyzed cities increased dramatically during the 500-year flood, reaching twice or more losses. In addition, the economic loss resulting from the fatalities can reach up to $\$ 395 \mathrm{M}$ and $\$ 1.9 \mathrm{~B}$ under the 100 and 500-yr flood events, respectively.

Table 7: The fatality rate and economic losses (\$) for the analyzed communities

\begin{tabular}{|c|c|c|c|c|}
\hline \multirow[b]{2}{*}{ Cities } & \multicolumn{2}{|c|}{ No. of life losses } & \multicolumn{2}{|c|}{$\begin{array}{l}\text { Fatalities to } 2021 \text { dollars } \\
\text { (\$7.9M/life; FEMA, 2016) }\end{array}$} \\
\hline & $100-y r$ & $500-y r$ & $100-y r$ & $500-y r$ \\
\hline Cedar Rapids & 14 & 30 & $\$ 111 \mathrm{M}$ & $\$ 237 \mathrm{M}$ \\
\hline Waterloo & 20 & 245 & $\$ 158 \mathrm{M}$ & $\$ 1,936 \mathrm{M}$ \\
\hline Cedar Falls & 12 & 75 & $\$ 95 \mathrm{M}$ & $\$ 593 \mathrm{M}$ \\
\hline Charles City & 50 & 68 & $\$ 395 \mathrm{M}$ & $\$ 529 \mathrm{M}$ \\
\hline Independence & 4 & 18 & $\$ 32 \mathrm{M}$ & $\$ 134 \mathrm{M}$ \\
\hline
\end{tabular}


This manuscript is an EarthArXiv preprint and has not been peer-reviewed before. Subsequent versions of this manuscript may have slightly different content.
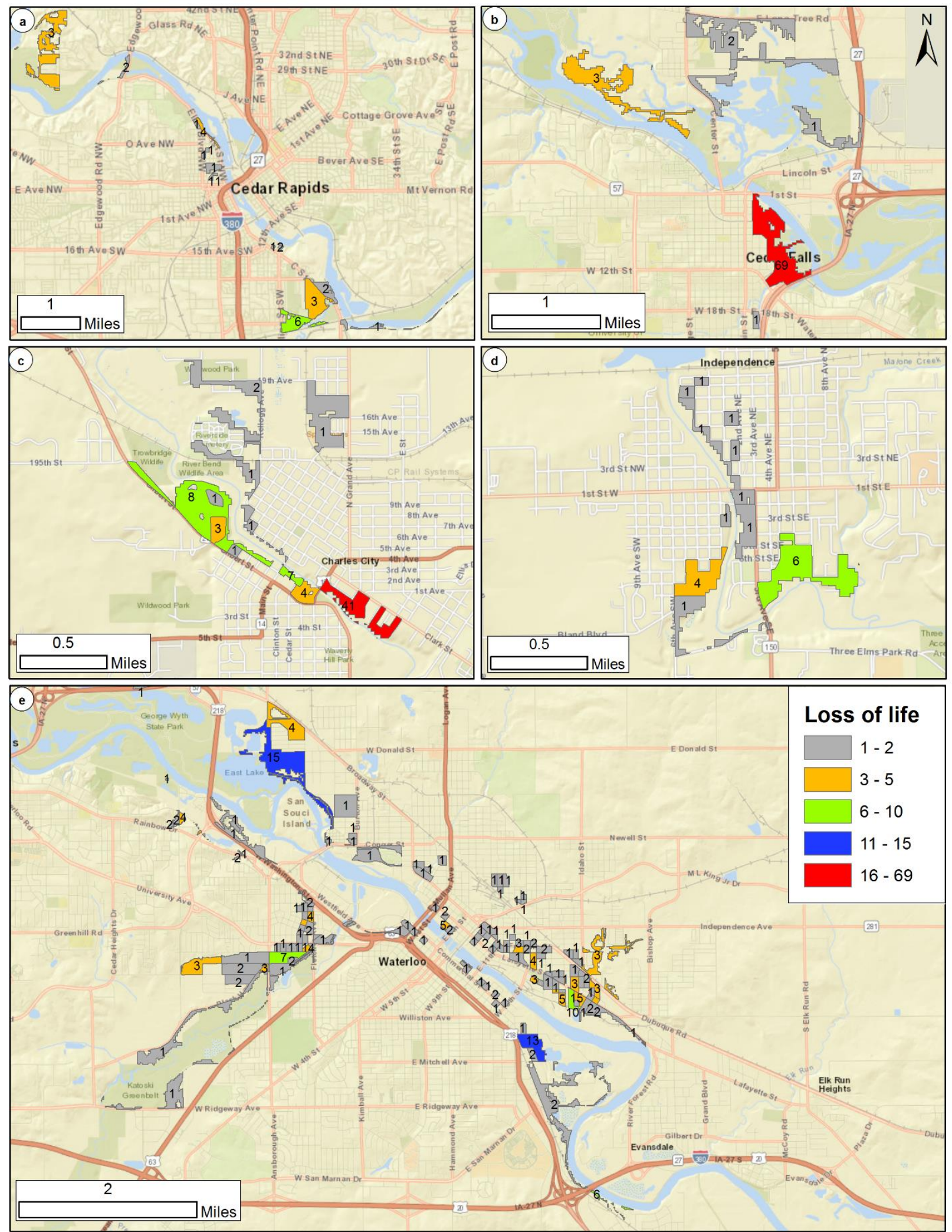

Figure 9: The potential life losses per impacted census block during the 500-yr flood scenario for Cedar Rapids (a), Cedar Falls (b) Charles City (c), Independence (d), and Waterloo (e). 
This manuscript is an EarthArXiv preprint and has not been peer-reviewed before. Subsequent versions of this manuscript may have slightly different content.

The life loss estimates are spatially represented per census block during the 500-yr flood event (Figure 9). Some blocks are expected to lose up to 40 people's lives, as in Cedar Falls and Charles City. These maps can illustrate the most vulnerable census block in terms of life loss. Therefore, mitigation strategies can take place, such as allocating shelters or prioritizing the evacuation areas.

\subsection{Floodplain Vulnerability}

Due to data availability, two cities are chosen for studying the comprehensive flood behavior impact. Figure 10 shows the interaction between flood depth and velocity during the $100-\mathrm{yr}$ and 500-yr flood events for Iowa City and Adel communities. These maps can inform decisionmakers of a wide flood risk planning and management (Carson et al., 2018), including the decision on road avoidance or entering, pedestrian safety, amenity and shelter locations, mitigation allocation, where to develop new lands, and critical evacuation locations. Also, it would be beneficial to transform the analysis into open-access interactive maps (Hu and Demir, 2021), so the public can be aware of risk easily and prepare well.

Table 8: The area and the number of buildings and roads within floodplain vulnerability regions

(Figure 6).

\begin{tabular}{|c|c|c|c|c|c|c|c|c|c|c|c|c|}
\hline & \multicolumn{9}{|c|}{ Iowa City } & \multicolumn{5}{c|}{ Adel City } \\
\cline { 2 - 17 } & \multicolumn{2}{|c|}{$\begin{array}{c}\text { Area } \\
\left(\mathbf{m i}^{2}\right)\end{array}$} & \multicolumn{2}{c|}{ Buildings } & \multicolumn{2}{c|}{$\begin{array}{c}\text { Road } \\
\text { segments }\end{array}$} & \multicolumn{2}{c|}{$\begin{array}{c}\text { Area } \\
\left(\mathbf{m i}^{\mathbf{2}}\right)\end{array}$} & \multicolumn{2}{c|}{ Buildings } & \multicolumn{2}{c|}{$\begin{array}{c}\text { Road } \\
\text { segments }\end{array}$} \\
\hline $\begin{array}{c}\text { Floodplain } \\
\text { vulnerability }\end{array}$ & $\begin{array}{c}100 \\
\mathrm{yr}\end{array}$ & $\begin{array}{c}500 \\
\mathrm{yr}\end{array}$ & $\begin{array}{c}100 \\
\mathrm{yr}\end{array}$ & $\begin{array}{c}500 \\
\mathrm{yr}\end{array}$ & $\begin{array}{c}100 \\
\mathrm{yr}\end{array}$ & $\begin{array}{c}500 \\
\mathrm{yr}\end{array}$ & $\begin{array}{c}100 \\
\mathrm{yr}\end{array}$ & $\begin{array}{c}500 \\
\mathrm{yr}\end{array}$ & $\begin{array}{c}100 \\
\mathrm{yr}\end{array}$ & $\begin{array}{c}500 \\
\mathrm{yr}\end{array}$ & $\begin{array}{c}100 \\
\mathrm{yr}\end{array}$ & $\begin{array}{c}500 \\
\mathrm{yr}\end{array}$ \\
\hline$H 1$ & 0.74 & 0.75 & 2,090 & 1,591 & 129 & 157 & 0.18 & 0.15 & 38 & 78 & 31 & 28 \\
\hline$H 2$ & 0.45 & 0.56 & 41 & 2,243 & 44 & 122 & 0.12 & 0.12 & 16 & 34 & 23 & 25 \\
\hline$H 3$ & 0.77 & 1.28 & 120 & 581 & 19 & 100 & 0.37 & 0.32 & 13 & 24 & 17 & 26 \\
\hline$H 4$ & 0.06 & 0.32 & 0 & 5 & 1 & 18 & 0.59 & 0.47 & 10 & 17 & 9 & 9 \\
\hline$H 5$ & 0.49 & 0.43 & 0 & 5 & 1 & 1 & 0.83 & 1.19 & 5 & 12 & 5 & 8 \\
\hline$H 6$ & 0.06 & 0.29 & 0 & 0 & 0 & 0 & 0.31 & 0.34 & 0 & 0 & 3 & 3 \\
\hline
\end{tabular}

We examined the building locations acquired from County Tax Office and Microsoft building footprint dataset, and road segments from Open Street Maps (OSM) located inside the risk maps. We found many buildings and roads categorized as unsafe for people, vehicles, and buildings (Table 8). During the 100 and 500-yr flood scenarios, the largest vulnerable zone is within the Iowa City floodplain that is unsafe for children, the elderly, and vehicles, while the unsafe areas for people, vehicles, and buildings (without special requirements) are the largest for Adel city. There are 41 building locations categorized as unsafe for small vehicles in Iowa City under the 100-yr flood, and the number goes up to 2,243 buildings during the 500-yr flood. Also, up to 120 Iowa road segments intersect with unsafe zones. Most of the vulnerable Adel buildings and roads fall in the zone classified as unsafe for children, the elderly, and vehicles. Floodplain 
vulnerability classification could enhance flood risk management and minimize the flood losses by using techniques to reduce the flood velocity.
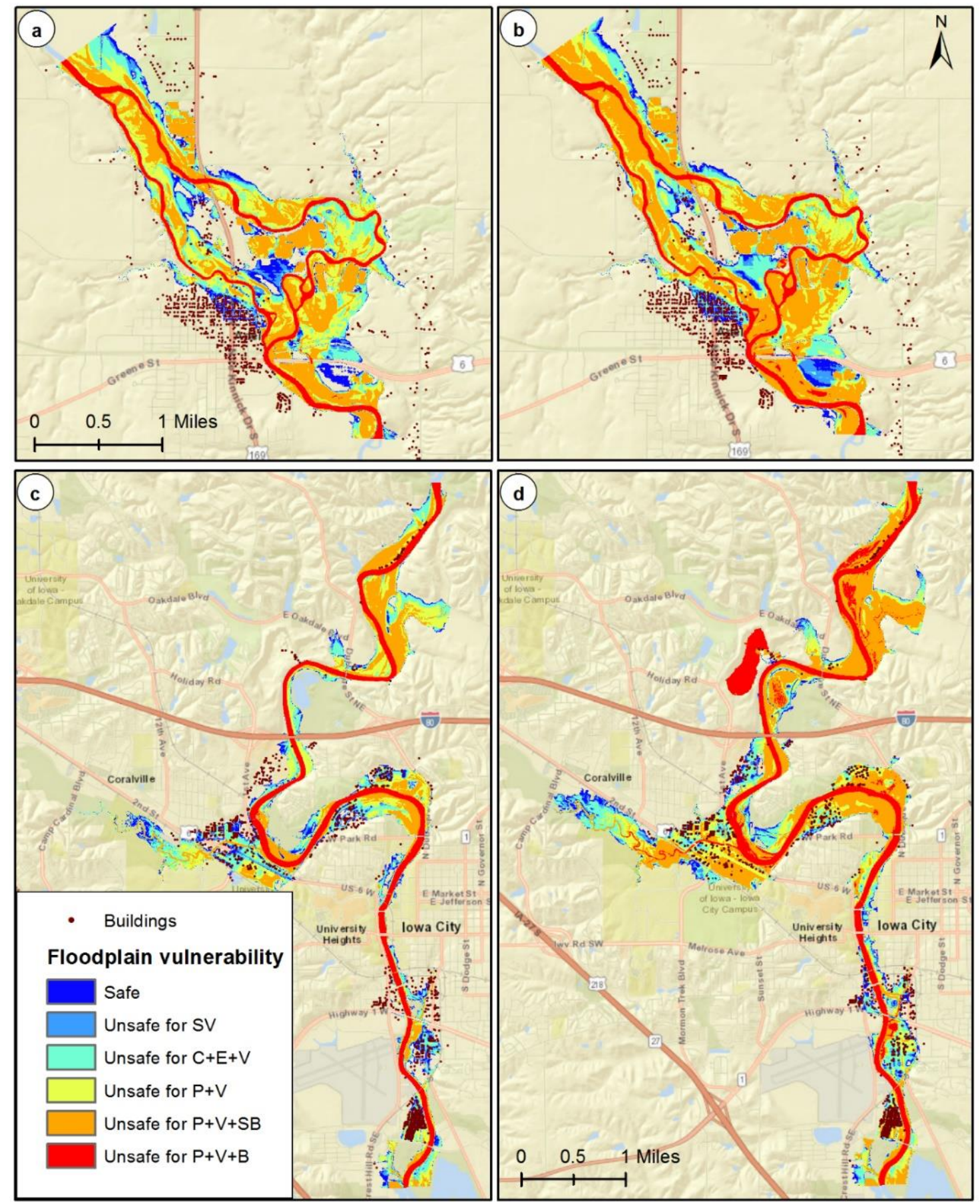

Figure 10: Floodplain vulnerability classification during the 100-yr flood (left) and 500-yr flood (right) for Adel (a, b) and Iowa City (c, d); SV: small vehicles, C: children, E: elderly, V: all vehicles, $\mathrm{P}$ : all people, SB: structural buildings or buildings without special requirements, $\mathrm{B}$ : all buildings). 


\subsection{Limitations}

Conducting flood impact analysis requires obtaining detailed datasets regarding buildings and infrastructure with advanced flood models. This research attempts to provide comprehensive flood impact analysis using freely available data. However, data quality and analysis assumptions may affect the results but still can provide a useful estimate for communities. One of the challenges in this research is the absence of accurate spatial building representation with detailed information. Even though County Tax Office data can provide accurate spatial representation; however, it lacks critical information (e.g., population information, foundation type) that may affect the accuracy of the analysis. The analysis assumed that all vehicles were subjected to flooding without considering the possibility of moving the vehicles out of the hazard areas before flooding. Also, flood impact assessment (e.g., health impacts) from systems like HAZUS can be limited and uncertain at some scale levels. In addition, covering a wide range of flood impacts can be a challenge for communities with limited resources. The absence of a detailed high-resolution flood behavior model (i.e., depth, velocity, duration, and arrival time) may restrict life loss assessment and other flood impact analysis. It requires an extensive process that may be a challenge in most cases communities with limited resources. Our analysis relied on only flood depth and assumed all people occupied their houses during flooding. The results are still important to ensure people's safety staying at their homes during flooding and determine the most vulnerable areas for life losses. Analyzing the floodplain vulnerability using the flood depth-velocity interaction should not be limited to higher flood return periods (i.e., 100-yr) but include different time intervals to understand the worst flood behavior (Smith et al., 2014).

\section{Conclusion}

With the increase in the frequency and magnitude of flooding due to human activities and climate change, flood impact analysis is a crucial stage to enhance the flood risk management cycle (i.e., planning) and, as a result, strengthen community resilience. This study carried out comprehensive flood damage and loss estimation analysis for several Iowa communities during the 100 and 500-yr flood scenarios. It has been found that flooding can generate costly economic impacts on essential facilities, infrastructure, businesses, and vehicles. That may be attributed to the higher number of buildings located in the floodplain. Besides, we noticed that some essential facilities (e.g., schools) lie within the floodplain and become non-functional during flooding, which may raise questions about location-allocation without accounting for flood scenarios. Also, our findings illustrate significant human impacts, such as loss of life, as seen in Charles City and Waterloo. During large-scale flooding, some of the Iowa City and Adel flood-prone locations were spatially classified as unsafe for people, vehicles, and buildings. Providing detailed information about vulnerable population and areas due to flooding in real-time and accessible platforms could open paths for improvements to minimize the consequences of flooding. Results can be used for existing policy improvement, land use, river basin, and emergency planning, and tell us which and where the mitigation efforts would be more effective. 
Future research can transform this study into a web-based geospatial analytical system (Xu et al., 2019) or integrate it into virtual reality environments (Sermet and Demir, 2020) that promote easily accessible flood impact information for decision-makers, including the public. Mitigation strategies are often evaluated by only the structure and content values of the buildings for the benefit-cost analysis. Our detailed economic and human impacts (e.g., income and life losses) can increase the benefits of implementing such measures at the community and property level. Advanced flood loss analysis components (i.e., arrival time) can be utilized to investigate the evacuation of people dynamically from hazard areas in order to assess people's lives caught in buildings or streets.

\section{References}

Agliamzanov, R., Sit, M. and Demir, I., 2020. Hydrology@ Home: a distributed volunteer computing framework for hydrological research and applications. Journal of Hydroinformatics, 22(2), pp.235-248. https://doi.org/10.2166/hydro.2019.170

Australian Institute for Disaster Resilience (AIDR), 2017. Flood Hazard. Australian Disaster Resilience Handbook Collection. Guideline 7-3.

Alabbad, Y., Mount, J., Campbell, A.M. and Demir, I., 2021. Assessment of transportation system disruption and accessibility to critical amenities during flooding: Iowa case study. Science of The Total Environment, p.148476. https://doi.org/10.1016/j.scitotenv.2021.148476

Alabbad, Y., Yildirim, E. and Demir, I., 2022. Flood mitigation data analytics and decision support framework: Iowa Middle Cedar Watershed case study. Science of The Total Environment, p.152768. https://doi.org/10.1016/j.scitotenv.2021.152768

Arrighi, C., Oumeraci, H., Castelli, F., 2017. Hydrodynamics of pedestrians' instability in floodwaters. Hydrol. Earth Syst. Sci. 21, 515-531. https://doi.org/10.5194/hess-21-5152017

Atoba, K. O., Brody, S. D., Highfield, W. E., \& Merrell, W. J., 2018. Estimating residential property loss reduction from a proposed coastal barrier system in the Houston-Galveston region. Natural Hazards Review, 19(3), 05018006. https://doi.org/10.1061/(ASCE)NH.1527$\underline{6996.0000297}$

Banks, J. C., J. V. Camp, and M. D. Abkowitz., 2014. “Adaptation planning for floods: A review of available tools." Nat. Hazard. 70 (2): 1327-1337. https://doi.org/10.1007/s11069-0130876-7.

Brackins, J. T., \& Kalyanapu, A. J., 2016. Using ADCIRC and HEC-FIA modeling to predict storm surge impact on coastal infrastructure. In World Environment and Water Resources Congress. https://ascelibrary.org/doi/pdf/10.1061/9780784479841\#page=213

Brody, S. D., Zahran, S., Highfield, W. E., Grover, H., \& Vedlitz, A., 2008. Identifying the impact of the built environment on flood damage in Texas. Disasters, 32(1), 1-18. https://doi.org/10.1111/j.1467-7717.2007.01024.x

Brown, C., Meeks, R., Ghile, Y., \& Hunu, K., 2013. Is water security necessary? An empirical 
This manuscript is an EarthArXiv preprint and has not been peer-reviewed before. Subsequent versions of this manuscript may have slightly different content.

analysis of the effects of climate hazards on national-level economic growth. Philosophical Transactions of the Royal Society A: Mathematical, Physical and

Engineering Sciences, 371(2002), 20120416. https://doi.org/10.1098/rsta.2012.0416

Cardona, O. D., Van Aalst, M. K., Birkmann, J., Fordham, M., Mc Gregor, G., Rosa, P., ... \& Thomalla, F., 2012. Determinants of risk: exposure and vulnerability. In Managing the risks of extreme events and disasters to advance climate change adaptation: special report of the intergovernmental panel on climate change (pp. 65-108). Cambridge University Press. https://doi.org/10.1017/CBO9781139177245.005

Carson, A., Windsor, M., Hill, H., Haigh, T., Wall, N., Smith, J., Olsen, R., Bathke, D., Demir, I. and Muste, M., 2018. Serious gaming for participatory planning of multi-hazard mitigation. International journal of river basin management, 16(3), pp.379-391. https://doi.org/10.1080/15715124.2018.1481079

Construction Industry Research and Information Association (CIRIA)., 2013. International levee handbook. London, UK.

Contributors., 2020. OpenStreetMap Wiki. Retrieved from https://wiki.openstreetmap.org/w/index.php?title=Contributors\&amp;oldid=2162996

Dun \& Bradstreet, 2006. Business Population Report aggregated by Standard Industrial Classification (SIC) and Census Block, May 2006.

Ewing, G. and Demir, I., 2021. An ethical decision-making framework with serious gaming: a smart water case study on flooding. Journal of Hydroinformatics, 23(3), pp.466-482. https://doi.org/10.2166/hydro.2021.097

Hammond, M. J., Chen, A. S., Djordjević, S., Butler, D., \& Mark, O., 2015. Urban flood impact assessment: A state-of-the-art review. Urban Water Journal, 12(1), 14-29.

https://doi.org/10.1080/1573062X.2013.857421

Homeland Infrastructure Foundation-Level Data (HIFLD), 2019. Open Data. Retrieved from https://hifld-geoplatform.opendata.arcgis.com/

FEMA., 2016a. Benefit-Cost Sustainment And Enhancements. Retrieved from https://www.caloes.ca.gov/RecoverySite/Documents/Benefit\%20Cost\%20Sustainment.pdf.

FEMA, 2016b. Resilience Report. Retrieved from https://dnr.wi.gov/topic/FloodPlains/documents/UpperFox_ResilienceReport.pdf.

FEMA., 2020a. Debris Removal. Retrieved from https://www.fema.gov/appeal/debris removal-1 .

FEMA., 2020b. Multi-hazard Loss Estimation Methodology, Flood Model. Retrieved from https://www.fema.gov/sites/default/files/2020-09/fema_hazus_flood-model_technicalmanual_2.1.pdf.

FEMA., 2021. Hazus Inventory Technical Manual. Retrieved from https://www.fema.gov/sites/default/files/documents/fema_hazus-inventory-technical-manual4.2.3.pdf.

Gutenson, J. L., A. A. Oubeidillah, P. Hicks, L. Durham, A. N. S. Ernest, L. Zhu, and X. Zhang, 2015. "Using HAZUS-MH and HEC-RAS to evaluate real world flooding events in the 
This manuscript is an EarthArXiv preprint and has not been peer-reviewed before. Subsequent versions of this manuscript may have slightly different content.

Upper Alabama River watershed.” In Proc., World Environmental and Water Resources Congress 2015, 1607-1627. Reston, VA: ASCE. https://doi.org/10.1061/9780784479162.157

Haltas, I., Yildirim, E., Oztas, F. and Demir, I., 2021. A comprehensive flood event specification and inventory: 1930-2020 Turkey case study. International Journal of Disaster Risk Reduction, 56, p.102086. https://doi.org/10.1016/j.ijdrr.2021.102086

Hu, A. and Demir, I., 2021. Real-Time Flood Mapping on Client-Side Web Systems Using HAND Model. Hydrology, 8(2), p.65. https://doi.org/10.3390/hydrology 8020065

Iowa Flood Center., 2020. Iowa Flood Inundation Maps. Retrieved from https://iowafloodcenter.org.

Iowa.gov., 2019. Office Of The Governor Of Iowa. Reterieved from https://governor.iowa.gov/2019/03/governor-reynolds-launches-211-flood-hotline-and-onestop-2019-iowa-floods-website-to-assist .

Jakob, M., Stein, D., Ulmi, M., 2012. Vulnerability of buildings to debris flow impact. Nat. Hazards 60 (2), 241-261. https://doi.org/10.1007/s11069-011-0007-2

Jonkman, S. N., Maaskant, B., Kolen, B., Zethof, M., \& Lehman, W., 2013. Loss of Life, Evacuation and Emergency Management: Comparison and application to case studies in the USA. DELFT UNIV OF TECHNOLOGY (NETHERLANDS). https://apps.dtic.mil/sti/citations/ADA577448

Matthews, V., Longman, J., Berry, H. L., Passey, M., Bennett-Levy, J., Morgan, G. G., ... \& Bailie, R. S., 2019. Differential mental health impact six months after extensive river flooding in rural Australia: a cross-sectional analysis through an equity lens. Frontiers in public health, 7, 367. https://doi.org/10.3389/fpubh.2019.00367

Mokhtari, F., Soltani, S., \& Mousavi, S. A., 2017. Assessment of flood damage on humans, infrastructure, and agriculture in the Ghamsar Watershed using HEC-FIA software. Natural Hazards Review, 18(3), 04017006. https://doi.org/10.1061/(ASCE)NH.1527-6996.0000248

NAI., 2014. How-to Guide for Infrastructure. Retrieved from https://asfpmlibrary.s3uswest2.amazonaws.com/FSC/NAI/ASFPM_NAI_Infrastructure 2016.pdf.

National Automobile Dealers Association (NADA). Retrieved from https://www.nada.org/ .

National Bridge Inventory, 2018. Bridges and Structures. Retrieved from https://www.fhwa.dot.gov/bridge/nbi.cfm.

NOAA National Centers for Environmental Information (NCEI) U.S. Billion-Dollar Weather and Climate Disasters (2021). https://www.ncdc.noaa.gov/billions/, DOI: 10.25921/stkw$7 \mathrm{w} 73$.

NOAA., 2014. Economic Assessment of Green Infrastructure Strategies for Climate Change Adaptation: Pilot Studies in The Great Lakes Region. Retrieved from https://coast.noaa.gov/data/digitalcoast/pdf/climate-change-adaptation-pilot.pdf .

Qiang, Y., 2019. Flood exposure of critical infrastructures in the United States. International Journal of Disaster Risk Reduction, 39, 101240. https://doi.org/10.1016/j.ijdrr.2019.101240 Radosavljevic, V., Belojevic, G., \& Pavlovic, N., 2017. Tool for decision-making regarding 
This manuscript is an EarthArXiv preprint and has not been peer-reviewed before. Subsequent versions of this manuscript may have slightly different content.

general evacuation during a rapid river flood. Public health, 146, 134-139.

https://doi.org/10.1016/j.puhe.2017.01.025

Sadler, J. M., Haselden, N., Mellon, K., Hackel, A., Son, V., Mayfield, J., ... \& Goodall, J. L. , 2017. Impact of sea-level rise on roadway flooding in the Hampton Roads region, Virginia. Journal of Infrastructure Systems, 23(4), 05017006. https://doi.org/10.1061/(ASCE)IS.1943555X.0000397.

Sermet, Y. and Demir, I., 2020. Virtual and augmented reality applications for environmental science education and training. In New Perspectives on Virtual and Augmented Reality (pp. 261-275). Routledge.

Sit, M., Sermet, Y. and Demir, I., 2019. Optimized watershed delineation library for server-side and client-side web applications. Open Geospatial Data, Software and Standards, 4(1), pp.110. https://doi.org/10.1186/s40965-019-0068-9

Smith, G.P., Davey, E.K., Cox, R.J., 2014. Flood hazard. Technical report 2014/07, Water Research Laboratory, University of New South Wales, Sydney.

Story County Iowa., 2018. Multi-Jurisdictional Hazard Mitigation Plan. Retrieved from https://cityofcollins.municipalimpact.com/documents/200/Story_County_IA_Hazard_Mitig ation_Plan_Update_2018_Final_-9.22_MB.pdf.

Tapia-Silva, F. O., Itzerott, S., Foerster, S., Kuhlmann, B., \& Kreibich, H., 2011. Estimation of flood losses to agricultural crops using remote sensing. Physics and Chemistry of the Earth, Parts A/B/C, 36 (7-8), 253-265. https://doi.org/10.1016/j.pce.2011.03.005

Teague, A., Sermet, Y., Demir, I. and Muste, M., 2021. A collaborative serious game for water resources planning and hazard mitigation. International Journal of Disaster Risk Reduction, 53, p.101977. https://doi.org/10.1016/j.ijdrr.2020.101977

United Nations., 2012. Disaster Risk and Resilience. Retrieved from https://www.un.org/en/development/desa/policy/untaskteam_undf/thinkpieces/3_disaste r_risk_resilience.pdf.

USACE., 2003. "Economic guidance memorandum (EGM) 04-01: Generic depth-damage relationships for residential structures with basements." Washington, DC.

USACE., 2018. HEC-FIA, Flood Impact Analysis User's Manual. Retrieved from https://www.hec.usace.army.mil/software/hec-fia/default.aspx .

USACE., 2020. HEC-LifeSim. Retrieved from https://www.hec.usace.army.mil/error.html?aspxerrorpath=/software/heclifesim/download.aspx .

US EPA., 2020. Green Infrastructure. Retrieved from Manage Flood Risk https://www.epa.gov/green-infrastructure/manage-flood-risk .

Wasko, C., Westra, S., Nathan, R., Orr, H. G., Villarini, G., Villalobos Herrera, R., \& Fowler, H. J., 2021. Incorporating climate change in flood estimation guidance. Philosophical Transactions of the Royal Society A, 379(2195), 20190548. https://doi.org/10.1098/rsta.2019.0548 
This manuscript is an EarthArXiv preprint and has not been peer-reviewed before. Subsequent versions of this manuscript may have slightly different content.

Weber, L.J., Muste, M., Bradley, A.A., Amado, A.A., Demir, I., Drake, C.W., Krajewski, W.F., Loeser, T.J., Politano, M.S., Shea, B.R. and Thomas, N.W., 2018. The Iowa Watersheds Project: Iowa's prototype for engaging communities and professionals in watershed hazard mitigation. International journal of river basin management, 16(3), pp.315-328. https://doi.org/10.1080/15715124.2017.1387127

World Bank., 2014. Understanding risk: Review of open source and open access software packages available to quantify risk from natural hazards. Washington, United States: World Bank Group. Available online from http://documents.worldbank.org/curated/en/109501468327344629 .

Xia, J., Falconer, R.A., Wang, Y., Xiao, X., 2014. New criterion for the stability of a human body in floodwaters. J. Hydraul. Res. 52 (1), 93-104. https://doi.org/10.1080/00221686.2013.875073

Xu, H., Demir, I., Koylu, C. and Muste, M., 2019. A web-based geovisual analytics platform for identifying potential contributors to culvert sedimentation. Science of the Total Environment, 692, pp.806-817. https://doi.org/10.1016/j.scitotenv.2019.07.157

$\mathrm{Xu}, \mathrm{H} .$, Muste, M. and Demir, I., 2019. Web-based geospatial platform for the analysis and forecasting of sedimentation at culverts. Journal of Hydroinformatics, 21(6), pp.1064-1081. https://doi.org/10.2166/hydro.2019.068

Xu, H., Windsor, M., Muste, M. and Demir, I., 2020. A web-based decision support system for collaborative mitigation of multiple water-related hazards using serious gaming. Journal of environmental management, 255, p.109887. https://doi.org/10.1016/j.jenvman.2019.109887

Yildirim, E. and Demir, I., 2019. An integrated web framework for HAZUS-MH flood loss estimation analysis. Natural Hazards, 99(1), pp.275-286. https://doi.org/10.1007/s11069-019$\underline{03738-6}$

Yildirim, E. and Demir, I., 2021a. An Integrated Flood Risk Assessment and Mitigation Framework: A Case Study for Middle Cedar River Basin, Iowa, US. International Journal of Disaster Risk Reduction, 56, p.102113. https://doi.org/10.1016/j.ijdrr.2021.102113

Yildirim, E. and Demir, I., 2021b. Flood Risk Assessment and Quantification at the Community and Property Level in the State of Iowa. EarthArxiv, 2803. https://doi.org/10.31223/X5TC92

Zhang, W., Villarini, G., Vecchi, G. A., \& Smith, J. A., 2018. Urbanization exacerbated the rainfall and flooding caused by hurricane Harvey in Houston. Nature, 563(7731), 384-388. https://doi.org/10.1038/s41586-018-0676-Z 